London

Cite this as: $B M J 2020 ; 371: m 4796$ http://dx.doi.org/10.1136/bmj.m4796 Published: 11 December 2020

\section{Covid-19: Test and trace system must improve its below par performance, NAO concludes}

\author{
Jacqui Wise
}

England's test and trace service must improve its performance because laboratories are working well below capacity, the public spending watchdog has said, as only $38 \%$ of tests are turned around within 24 hours and just two thirds of contacts of infected people are reached and told to self-isolate.

The detailed report from the National Audit Office (NAO) ${ }^{1}$ acknowledges that the Department of Health and Social Care rapidly scaled up its covid-19 testing and tracing system from scratch. It reached a target of having capacity for 500 ooo tests a day on 31 October and is working to reach 800 ooo a day by the end of January 2021. However, on average the number of tests carried out was only $68 \%$ of the published maximum capacity from May to October.

The target to provide results within 24 hours of in-person testing in the community has not been met. Turnaround within 24 hours peaked at $93 \%$ in June but fell to a low of $14 \%$ in mid-October before rising to $38 \%$ in early November. In comparison, $90 \%$ of results from tests conducted in hospitals and care homes are returned within 24 hours.

The NAO has also criticised leaders at NHS Test and Trace for not having planned for the sharp rise in testing demand in September when schools and universities reopened, which resulted in rationing of tests and large backlogs. Its report says that the service must learn lessons from its experience and be much better prepared for spikes in demand.

\section{Local integration}

Gareth Davies, head of the NAO, said, “Test and Trace is core to the UK's pandemic response. It must improve its performance with a focus on effective engagement with the public and integration with local efforts to improve tracing."

The watchdog has voiced reservations about whether the €22bn (€24bn; \$29.1bn) test and trace budget for 2020-21 is being well spent. Contracts worth $€ 7 b n$ have been signed with 217 public and private organisations to provide supplies, services, and infrastructure, and $70 \%$ of early contracts by value were directly awarded under emergency measures without competition. The 84 page NAO report is the first of two publications on testing and tracing, and a second-due out in spring 2021-will provide a fuller assessment of value for money.

The proportion of people who tested positive and were reached by contact tracers increased from $73 \%$ at the end of May to $85 \%$ at the end of October.

However, the proportion of close contacts who were reached dropped from $91 \%$ to $60 \%$ in the same period. The proportion of contacts reached by the national tracing service within 48 hours was $87 \%$ at the end of May, but this dropped to $64 \%$ in mid-October before rising to $81 \%$ by the end of October.

The report notes that central call handler contracts with Serco and Sitel are worth as much as $£ 720 \mathrm{~m}$ but that, at times, parts of the national tracing service have been barely used. By 17 June the proportion of time that call handlers actively worked during their paid hours was just $1 \%$. The government has now reduced the number of call handlers, but rates of use remained below a 50\% target throughout September and much of October.

\section{"Unusual" relationships}

The report says that the government did not document the basis for its chosen delivery model until it published its business case in September 2020. Many stakeholders queried why the government did not involve local authorities more in its initial approach to tracing, as occurs in many other countries.

Since July local authorities have assumed a bigger tracing role, setting up their own schemes in conjunction with the national arrangements. By the end of October $40 \%$ of local authorities had set up a local tracing scheme, and a further $46 \%$ planned to set one up. However, some local government stakeholders told the NAO that they were being held back from developing their own arrangements because of a lack of funding.

Meg Hillier, chair of the Public Accounts Committee, commented, "The government tried to reinvent the wheel when it centralised testing and tracing, tearing up the usual accountability arrangements and leaving local public health teams out in the cold. The government needs to urgently work out what's going wrong at every step of the process. Throwing more money at the problem clearly isn't the answer."

Jennifer Dixon, chief executive of the Health Foundation, said, "NHS Test and Trace needs to better use the expertise and knowledge

of local authorities when designing improvements to the system. And the government needs to ensure that local authorities are sufficiently resourced if they are to play a larger role in rolling out mass testing and local contact tracing."

The report also questions the "unusual organisational relationship" of NHS Test and Trace with the Department of Health and Social Care. It highlights risks of "unclear accountability," as the service's head, Dido Harding, reports directly to the prime minister and the cabinet secretary rather than the department's ministers, although the NAO says that it has not done a systematic review to determine whether these risks have materialised. 
Billy Palmer, senior fellow at the Nuffield Trust, said, “As the report points out, we need to ask questions about NHS Test and Trace's unusual organisational relationships and unclear accountability. The centralised nature of the programme and the limited support and incentives for people to isolate may also be significant problems."

1 National Audit Office. The government's approach to test and trace in England-interim report. Dec 2020. https://www.nao.org.uk/report/the-governments-approach-to-test-and-trace-in-england-interim-report/.

This article is made freely available for use in accordance with BMJ's website terms and conditions for the duration of the covid-19 pandemic or until otherwise determined by BMJ. You may use, download and print the article for any lawful, non-commercial purpose (including text and data mining) provided that all copyright notices and trade marks are retained. 